\author{
Anna MOROZ (D) \\ Uniwersytet w Białymstoku \\ anna.moroz@tlen.pl
}

\title{
PAMIĘĆ I (NIE)PAMIĘĆ: O BURZENIU CERKWI PRAWOSŁAWNYCH NA CHEŁMSZCZYŹNIE I POEUDNIOWYM PODLASIU W 1938 ROKU
}

ABSTRACT Memory and (Non)Memory: The Destruction of Orthodox Churches in the Chełm Region and southern Podlasie in 1938

In the article, I will present the history of the destruction of Orthodox churches in the Chelm region and southern Podlasie in Poland in 1938. This incident is an important element in the process of symbolizing the existence of the Orthodox Church in Poland, which is why the memory of trauma is a feature of the memory of Orthodox people. This incident does not actually exist in the public discourse, it is unknown, and what is more, it does not fit the common Polish perception of the Second Polish Republic. The trauma of this incident in the Orthodox community is part of the post-memory discourse, which means that the next generations also experience trauma.

Keywords: memory, non-memory, memory conflict, minority, Orthodoxy

Słowa kluczowe: pamięć, niepamięć, konflikt pamięci, mniejszość, prawosławie 
W historii Polski możemy odnaleźć wydarzenia, które dotyczą nie tyle i nie tylko bezpośrednio Polaków, ale także w równym stopniu przedstawicieli innych nacji i wyznań zamieszkujących w określonym czasie Polskę. Znaczenie nadawane tym wypadkom zależne jest od stopnia ich doniosłości dla grupy, dlatego, jak można się domyślać, fakt, który był/jest doniosły dla mniejszości przez wzgląd na zasadniczą ingerencję w jej funkcjonowanie, nie będzie miał takiej samej wagi dla większości, nie zaburza bowiem jej bytu bądź czyni to w niewielkim stopniu. Tym samym jedne historie są upamiętniane, o drugich zaś się zapomina; często dotyczy to tego samego wydarzenia, które jednej ze stron zapada w pamięć - memorable - dla drugiej strony przeciwnie, jest ono takim, o którym można zapomnieć - forgettable.

Jedną $\mathrm{z}$ takich historii $\mathrm{w}$ polskim repertuarze pamięci wydaje się burzenie cerkwi prawosławnych w II RP, nazywane potocznie „akcją burzenia cerkwi na Chełmszczyźnie i południowym Podlasiu”. Zanim jednak przejdę do rozważań nad pamięcią i „niepamięcią" o niej, warto przybliżyć, czym było to wydarzenie i w jakich okolicznościach historycznych się rozgrywało ${ }^{1}$.

\section{RYS HISTORYCZNY}

Polska po odzyskaniu niepodległości w 1918 r. stała się krajem wielonarodowym i wielowyznaniowym. W strukturze narodowej młodego państwa mniejszości stanowiły ponad 30\%. Jednym z głównych problemów była kwestia integracji terytorialnej i społecznej, trudna zwłaszcza w odniesieniu do ziem wschodnich, pogranicznych, zamieszkiwanych licznie przez mniejszości białoruską i ukraińską (wykazującą tendencje separatystyczne po nieudanej próbie budowy własnego państwa²).

Prawosławie w II RP było drugim pod względem ilości wyznawców Kościołem, jednak ciągle Kościołem mniejszościowym, który utracił swoją uprzywilejowaną pozycję, jaką miał pod zaborem rosyjskim. Wedle spisu powszechnego z 1931 r. państwo polskie zamieszkiwało 3,8 mln osób wyznania prawosławnego, co stanowiło ponad $11 \%$ w skali kraju³ . Byli to głównie Ukraińcy, Białorusini oraz tzw. tutejsí.

1 Burzenie cerkwi prawosławnych na Chełmszczyźnie i południowym Podlasiu, a zwłaszcza pamięć, niepamięć i postpamięć dotyczące tych wydarzeń, są tematem mojej rozprawy doktorskiej i przedmiotem aktualnie prowadzonych przeze mnie badań w tym zakresie. Badania te skupiają się wokół wywiadów pogłębionych z osobami, których rodzice/dziadkowie bezpośrednio doświadczyli skutków burzenia cerkwi/ byli jej świadkami. Ponadto analizie poddane są również dane zastane w postaci prasy mniejszościowej.

2 M. Papierzyńska-Turek, Uwarunkowania i skutki polityczne masowego burzenia cerkwi prawostawnych u schytku II Rzeczpospolitej, [w:] Akcja burzenia cerkwi prawostawnych na Chetmszczyźnie i Potudniowym Podlasiu w 1938 roku. Uwarunkowania, przebieg konsekwencje, red. G. Kuprianowicz, przeł. M. Łukaszuk-Piekara, A. Saweneć, Chełm 2009, s. 33.

3 Historia Polski w liczbach. Ludnośc, terytorium, Główny Urząd Statystyczny, oprac. A. Wyczyński i in., red. F. Kubiczek i in., Warszawa 1993, s. 158.

4 Ludność mówiąca gwarą języka ukraińskiego i białoruskiego o niesprecyzowanej świadomości narodowej zamieszkująca głównie Polesie. 
Prawosławie w II RP było jednak kojarzone przede wszystkim z caratem rosyjskim i jego pozostałością na ziemiach polskich - pomijano również własne historyczne dziedzictwo, spuściznę dawnej Rzeczpospolitej, której prawosławie było częścią5. $\mathrm{Na}$ ten stan wpłynęły zwłaszcza zabory, dlatego Kościół prawosławny - a tym samym jego świątynie - był postrzegany w kontekście jednego z reliktów tych czasów. Z pewnością przyczyniły się do tego same władze carskie, które w ramach polityki rusyfikacyjnej wzniosły na ziemiach polskich wiele obiektów cerkiewnych, mających być symbolem ich panowania (np. sobór pw. św. Aleksandra Newskiego na placu Saskim w Warszawie) $)^{6}$.

Wszystko to powodowało nieufność, a nawet wrogość wobec Kościoła prawosławnego oraz jego duchowieństwa, które utożsamiano z zaborcą. W konsekwencji władze państwowe obrały dwa kierunki polityki w stosunku do Cerkwi - ograniczenie jej stanu posiadania i wpływów (majątek, świątynie, parafie) oraz uporządkowanie organizacyjne celem uzależnienia od państwa, a w dalszej perspektywie polonizacja, ze szczególnym naciskiem na tereny Chełmszczyzny i Podlasia, gdzie występowało największe poczucie odrębności ludności miejscowej ${ }^{7}$ Warto zaznaczyć, że niechęć do Kościoła prawosławnego w Polsce wynikała również po części z analogicznego podejścia do Kościoła unickiego w okresie zaborów w obrębie zaboru rosyjskiego. Dochodziło wówczas do likwidacji parafii unickich i faktycznej delegalizacji Kościoła unickiego, a tym samym do jego „wchłonięcia” przez Rosyjską Cerkiew Prawosławną̧.

Tak ukierunkowana polityka przyczyniła się do niechęci względem prawosławia, a w dalszej perspektywie do wszczęcia akcji rewindykacyjnej świątyń i monasterów,

M. Papierzyńska-Turek Uwarunkowania i skutki polityczne..., s. 34. Teza o tym, że prawosławie jest elementem obcym kulturowo na terenie Polski, jest mylna, gdyż początki chrześcijaństwa wschodniego na tych ziemiach były związane z misją metodiańską na ziemiach polskich oraz obrządkami bizantyjskim i ruskim. Istnienie obrządku słowiańskiego (powstałego w wyniku misji metodiańskiej wśród Słowian) na ziemiach polskich ma potwierdzenie w źródłach pisanych; ośrodki kultu nie były pod kontrolą Kościoła łacińskiego, pozostawały pod wpływem cywilizacji bizantyjskiej z liturgią słowiańską i pismem cyrylickim. Państwo pierwszych Piastów miało trwałe granice zachodnie, granica wschodnia była jednak płynna i nie oznaczała zasięgu chrześcijaństwa. Polska od momentu formowania się struktury państwowej przez całe średniowiecze była na szlaku krzyżujących się wpływów Wschodu i Zachodu. Por. A. Mironowicz, Kościót prawostawny w dziejach dawnej Rzeczypospolitej, Białystok 2001.

6 A. Mironowicz, Kościót prawostawny na ziemiach polskich w XIX i XX wieku, Białystok 2005, s. 124.

G. Kuprianowicz, 1938. Akcja burzenia cerkwi prawostawnych na Chetmszczyźnie i Potudniowym Podlasiu, przeł. A. Saweneć, Chełm 2008, s. 11.

8 W zaborze rosyjskim w 1875 r. władze carskie dokonały likwidacji ostatnich parafii unickich, co równało się z likwidacją Kościoła unickiego. Wszystkich unitów wraz z ich administracją, świątyniami, elementarzem przymusowo włączono do Rosyjskiej Cerkwi Prawosławnej. W tych i innych działaniach należy upatrywać prześladowania tego Kościoła pod zaborem rosyjskim. W 1905 r. car wydał ukaz tolerancyjny znoszący prawo zakazujące poddanym rosyjskim zrywania z prawosławiem, na mocy którego przymusowo włączeni do Cerkwi unici mogli zadeklarować, że są katolikami obrządku łacińskiego - bez odzyskania majątku ruchomego i nieruchomego Kościoła unickiego oraz bez możliwości jego odrodzenia. Stąd też m.in. późniejsza chęć odzyskania - „rewindykacji” - majątku pounickiego przez Kościół katolicki w II RP. Por. H. Dylągowa, Dzieje unii brzeskiej (1596-1918), Warszawa-Olsztyn 1996. 
organizowanej przez administrację państwową i Kościół rzymskokatolicki ${ }^{9}$, co zapoczątkowało utratę cerkwi przez Kościół prawosławny w okresie międzywojennym.

Samą akcję rewindykacyjną prawosławnych obiektów sakralnych można podzielić na trzy etapy, spośród których obejmujący najbardziej radykalne działania i niejako „ostateczny” przypada na ostatnie lata okresu międzywojennego, tj. 1937-1939, kiedy zgodnie z poczynionymi założeniami dokonywano burzenia prawosławnych świątyń ${ }^{10}$.

\section{AKCJA BURZENIA CERKWI}

Choć proces wyburzania/rozbiórki cerkwi prawosławnych w II RP miał miejsce od 1919 r., niszczono świątynie będące w opinii większości symbolami caratu (ponad 30 cerkwi, w tym sobór na placu Saskim w Warszawie), co miało charakter żywiołowy i irracjonalny oraz raczej incydentalny ${ }^{11}$.

U schyłku okresu międzywojennego rozbiórka świątyń miała charakter zdecydowanie zorganizowany, a jej inicjatorami były władze państwowe. Oficjalną przesłanką do wyburzania świątyń było założenie, że cerkwie te nie są potrzebne oraz były wybudowane w ramach rusyfikacji. Faktyczny powód stanowiło dążenie władz do osłabienia ruchu białoruskiego i ukraińskiego poprzez likwidację parafii i czynnych cerkwi ${ }^{12}$. Był to wynik przeświadczenia, że pozostawienie na tym terenie prawosławnych świątyń czy domów modlitwy przyniesie większe zagrożenie dla polonizacji tego terenu niż ich

$9 \quad$ A. Mironowicz, Kościót prawostawny na ziemiach..., s. 84.

10 Pierwszy etap akcji rewindykacyjnej przypadł na lata 1918-1924, kiedy postanowiono uregulować sprawy majątkowe mienia cerkiewnego. Mianowicie w 1919 r. państwo odebrało Cerkwi prawo do dysponowania jej dotychczasowym majątkiem (por. G. Kuprianowicz, 1938. Akcja burzenia cerkwi..., s. 17), co w praktyce oznaczało przejęcie pod przymusowy zarząd państwowy wszystkich nieruchomości należących do Kościoła prawosławnego, rzekomo z powodu roztoczenia opieki nad opuszczonymi w wyniku wojny cerkwiami i dobrami cerkiewnymi. Na skutek tych działań pokaźna liczba świątyń prawosławnych została zamknięta i opieczętowana. Równocześnie władze państwowe pod naciskiem wiernych rzymskokatolickich masowo przekazywały im cerkwie prawosławne (por. A. Kinasz, Proces likwidacji prawostawnych cerkwi na Lubelszczyźnie w latach 1937-1938 w świetle relacji świadków, „Studia Sandomierskie. Teologia, filozofia, historia” 2010, vol. 17, nr 1-2, s. 88). Drugi okres rewindykacji przypadł na lata 1929-1934. Wszczęto wówczas procesy rewindykacyjne - episkopat rzymskokatolicki masowo składał pozwy majątkowe. Roszczeniami strony katolickiej została objęta niemal jedna trzecia całego majątku cerkiewnego - żądania dotyczyły świątyń, budynków parafialnych, majątków ziemskich, a także monasterów (por. S. Kiryłowicz, $Z$ dziejów prawostawia w II Rzeczypospolitej Polskiej. Niektóre problemy na tle polityki wyznaniowej państwa 1918-1939, Warszawa 1985, s. 54). Ta fala rewindykacji wywołała poczucie zagrożenia wśród mniejszości prawosławnej, a żądania zwrotu świątyń wysuwane przez katolicki episkopat uważano za pozbawione podstaw historycznych i prawnych (por. A. Mironowicz, Kościót prawostawny na ziemiach..., s. 132-133).

11 Tamże, s. 135.

12 Tamże, s. 136. 
likwidacja ${ }^{13}$. Samą akcję burzenia świątyń zakończono w momencie likwidacji ostatniej przewidzianej do rozebrania cerkwi ${ }^{14}$.

Najbardziej radykalne działania w postaci rozbiórek świątyń rozpoczęły się latem 1938 r. Oficjalnym tego powodem było usunięcie zbędnych, niszczejących cerkwi w miejscowościach, gdzie nie było osób prawosławnych, faktyczną przesłankę zaś stanowiło ograniczenie liczby cerkwi i zlikwidowanie nieczynnych, których otwarcia domagali się wierni ${ }^{15}$. W burzeniu nie przestrzegano żadnych zasad ani ustaleń. Burzono wszystko, co wydawato się wtadzom zbędne, zachowując Kościotowi prawostawnemu jedynie bezwzględne minimum ${ }^{16}$. Warto podkreślić, że wcześniej dokonano dokładnej analizy „sytuacji” wyznaniowo-narodowej w poszczególnych gminach, a nawet wsiach ${ }^{17}$.

Burzenie cerkwi odbywało się od połowy maja do połowy lipca 1938 r. Działania w tym zakresie były prowadzone przez lokalną administrację oraz komitety koordynacyjne. W akcji burzenia świątyń brała udział młodzież (zrzeszona w organizacjach polskich), wojskowi, oddziały saperów, więźniów i brygad robotniczych. Niszczono świątynie gromadzące nawet kilka tysięcy wiernych. Osoby prawosławne z zasady nie przeciwstawiały się rozbiórce $\mathrm{w}$ sposób siłowy ${ }^{18}$, co było podyktowane strachem przed jakimikolwiek działaniami ze względu na obecność policji i brak wiary w ich skuteczność ${ }^{19}$.

Świątynie niszczono pod ochroną wojska lub policji - w zależności od okoliczności - z psami, pałkami lub karabinami. Oddziały dokonujące rozbiórki przybywały zwykle rano, a nawet w nocy, w towarzystwie lokalnej administracji. Często niszczono całe wyposażenie cerkwi, jednocześnie je profanując, a także biblioteki czy archiwa, czasem też przycerkiewne cmentarze. W trakcie wyburzania ludność gromadziła się dookoła świątyni, obserwując jej rozbiórkę, czasem płacząc, próbując jednocześnie przekonywać urzędników do zmiany decyzji. Rozbiórka trwała od kilku godzin do kilkunastu dni w przypadku cerkwi murowanych. Pozostałości materiałów budowlanych sprzedawano lub np. przekazywano robotnikom, którzy niszczyli cerkwie; drewniane szkielety wykorzystywano na opał. Sami prawosławni właściwie nigdy nie mogli zabierać wyposażenia cerkwi czy materiałów z rozbiórki ${ }^{20}$.

W wyniku przeprowadzonego wyburzania świątyń, którego kulminacyjny punkt przypadł na lato 1938 r., zlikwidowano do lipca tegoż roku 127 prawosławnych

13 J. Kęsik, Udziat wojska w akcji rewindykacyjno-polonizacyjnej we wschodnich i potudniowych powiatach województwa lubelskiego w latach 1937-1939, „Kwartalnik Historyczny” 2014, vol. 121, nr 4, s. 811.

14 K. Grzesiak, Akcja burzenia cerkwi na Lubelszczyźnie w roku 1938 - konsekwencje kulturowe, „Roczniki Kulturoznawcze" 2013, vol. 4, nr 1, s. 12-16.

15 G. Kuprianowicz, 1938. Akcja burzenia cerkwi..., s. 41.

16 Tamże.

17 J. Kęsik, Udziat wojska wakcji rewindykacyjno-polonizacyjnej..., s. 803.

18 A. Mironowicz, Kościót prawostawny na ziemiach..., s. 137.

19 G. Kuprianowicz, 1938. Akcja burzenia cerkwi..., s. 47.

20 Tamże, s. 43-47. 
obiektów sakralnych, w tym 91 cerkwi, 10 kaplic i 26 domów modlitewnych ${ }^{21}$. Osiem cerkwi przejął Kościół katolicki ${ }^{22}$. Kościół prawosławny stracił w sumie jedną trzecią wszystkich świątyń.

\section{SKUTKI AKCJI BURZENIA CERKWI}

Bezpośrednim skutkiem burzenia cerkwi było uniemożliwienie osobom wyznania prawosławnego uczestniczenia w nabożeństwach. Część z tych osób została zmuszona do konwersji na katolicyzm, a inni z przymusu zaczęli uczęszczać do kościołów rzymskokatolickich, mając na uwadze, że była to najbliższa chrześcijańska świątynia. Pozostali udawali się do oddalonej wiele kilometrów funkcjonującej cerkwi, co wiązało się także $\mathrm{z}$ utrudnioną działalnością duszpasterską ${ }^{23}$.

Skutki opisanych wydarzeń są jednak bardziej zróżnicowane i rozciągnięte w czasie. Pierwszym tego przykładem jest radykalna zmiana kulturowa w krajobrazie Lubelszczyzny. Biorąc pod uwagę wartość zabytkową i kulturową utraconych świątyń, należy wskazać, że ucierpiały cerkwie będące cennymi regionalnymi zabytkami architektury sakralnej - rozebrano np. cerkwie w Białej Podlaskiej (z 1582 r.), Zamościu (z 1589 r.) czy Kołnyce (z 1578 r. $)^{24}$.

Ponadto nie liczono się z potrzebami religijnymi parafian, likwidując świątynie gromadzące od tysiąca do kilku tysięcy wiernych, a w trakcie tych działań profanując ikony czy księgi liturgiczne oraz inne wyposażenie ruchome o wartości zabytkowej i walorach historycznych oraz artystycznych. W okresie bezpośrednio następującym po burzeniu świątyń w społeczności prawosławnej podkreślano głównie straty moralne, wynikające ze zranienia uczuć religijnych wiernych Kościoła prawosławnego, oraz związany z tym żal i poczucie krzywdy ${ }^{25}$. Ważnym aspektem jest również nadszarpnięcie autorytetu państwa polskiego, zwłaszcza na obszarze pogranicza polsko-ukraińskiego ${ }^{26}$.

Bezpośrednio po tych wydarzeniach narastał strach przed kolejnymi represjami i niewiara w możliwość obrony swoich praw ${ }^{27}$. Co więcej, panowała atmosfera wzajemnej nieufności, a nawet wrogości, co skutkowało zrywaniem więzi sąsiedzkich w mieszanych wyznaniowo miejscowościach, brakiem kontaktów towarzyskich czy typowej dla wiejskich społeczności wzajemnej pomocy ${ }^{28}$.

21 P. Stawecki, Następcy komendanta. Wojsko a polityka wewnętrzna Drugiej Rzeczypospolitej w latach 1935-1939, Warszawa 1969, s. 194.

22 A. Mironowicz, Kościót prawostawny na ziemiach..., s. 140.

K. Grzesiak, Akcja burzenia cerkwi na Lubelszczyźnie..., s. 30.

24 A. Mironowicz, Kościót prawostawny na ziemiach..., s. 140.

25 K. Grzesiak, Akcja burzenia cerkwi na Lubelszczyźnie..., s. 30.

26 J. Kęsik, Udziat wojska wakcji rewindykacyjno-polonizacyjnej..., s. 830.

27 G. Kuprianowicz, 1938. Akcja burzenia cerkwi..., s. 65.

28 J. Kęsik, Udziat wojska wakcji rewindykacyjno-polonizacyjnej..., s. 829; K. Grzesiak, Diecezja lubelska wobec prawostawia w latach 1918-1939, Lublin 2010, s. 230. 
Burzenie cerkwi miało charakter traumatogenny dla całej społeczności prawosławnej, która go doświadczyła. Jest to równoznaczne z faktem, że wydarzenie to odbiło się na świadkach, będących obserwatorami całej akcji, ale też na ich dzieciach i wnukach, całej zbiorowości. Miało ono i w dalszym ciągu ma dalekosiężny wpływ na mniejszość prawosławną w Polsce - stanowi obecnie bardzo ważny element w procesie symbolizacji trwania Kościoła prawosławnego w Polsce, rozumianego zarówno jako instytucja, jak i zbiorowość. Mimo że w kontekście mniejszości wydarzeniu temu nadano wielkie znaczenie, w ramach kontekstu społecznego możemy obserwować brak uznania tej traumy, a więc też brak obiektywnego jej przepracowania i szeroko rozumianego zintegrowania w ramach panującego dyskursu i polityki historycznej.

W obrębie społeczności prawosławnej wydarzenie to i związana z nim trauma nie ulegają wyciszeniu. Cytując Prawosławnego Arcybiskupa Lubelskiego i Chełmskiego Abla: Te smutne stronice historii nie moga być zapomniane, powinny pozostać elementem naszej pamięci historycznej ${ }^{29}$. Z kolei zwierzchnik Polskiego Autokefalicznego Kościoła Prawosławnego w Polsce, Metropolita Warszawski i całej Polski Sawa, stwierdził, że: Dla wiernych Chetmszczyzny i Podlasia byta to Golgota, która wierny swojej wierze przeżyt lud prawostawny. Nie da się w petni opisać ogromu cierpień i strat w tym czasie. [...] Burzono to, co byto najcenniejsze dla Prawostawia: światynie, monastery, miejsca uświęcone modlitwa i krwia naszych przodków. Miejscowy lud prawostawny prześladowano za św. Wiarę Prawostawna, za trwanie w tradycji przodków. [...] Pamięć o tym, co się wydarzyto w 1938 r., niech dziś buduje nasze przywiazanie do św. Wiary Prawostawnej, do kultury, tradycji i jezyka naszych mężnych przodków oraz przypomina jak ważne jest przykazanie mitości bliźniego. Niechaj wydarzenia te będą też przestroga dla wszystkich, którzy chcieliby podnieść swa rękę na świątynię Boża, bowiem: »Jeżeli ktoś niszczy światynię Boga, tego i Bóg zniweczy, ponieważ jest ona święta « (1 Kor 3,17)

\section{(NIE)PAMIĘĆ}

Opisana historia burzenia cerkwi nie występuje w publicznym dyskursie (z pominięciem dyskusji na gruncie naukowo-historycznym) oraz w sferze powszechnej świadomości. Jest ona raczej przemilczana, przez co z owego dyskursu wyrugowana. Andrzej Rykała przedstawia to zjawisko, pisząc o „topografii pustki” w krajobrazie kulturowym $^{31}$. Inaczej mówiąc, historia ta należy do sfery zbiorowej nieświadomości.

Nieistnienie opisywanego tematu w przestrzeni publicznej można nazwać zbiorową „niepamięcią?. Jest to rodzaj luk w pamięci, które obejmują wszystko to, co

29 Abp. Abel (Popławski), Stowo Prawostawnego Arcybiskupa Lubelskiego i Chetmskiego, [w:] Akcja burzenia cerkwi prawostawnych na Chetmszczyźnie..., s. 12.

30 Metropolita Sawa (Hrycuniak), Wstęp, [w:]: G. Kuprianowicz, 1938. Akcja burzenia cerkwi..., s. 7.

31 A. Rykała, $O$ „topografii pustki” $w$ krajobrazie kulturowym. Miejsca niepamięci i nie-miejsca pamięci w kontekście mordów dokonanych na Żydach w Polsce w pierwszych miesiacach po drugiej wojnie świato$w e j$, „Studia z Geografii Politycznej i Historycznej” 2018, vol. 7, s. 93-132. 
nieprzyswojone, treści w jakiś sposób wyeliminowane czy zapomniane ${ }^{32},[\ldots]$ niepamięć to także wybieranie pewnych fragmentów pamięci, a przemilczanie, czy wręcz wykreślanie innych, niewygodnych ${ }^{33}$.

Zbiorowa niepamięć, rozumiana w opisywanym przypadku jako społeczna nieświadomość w zakresie istnienia opisywanego wydarzenia, ma swoje przyczyny. Można je podzielić na dwie grupy: przyczyny zewnętrzne, wynikające z przesłanek systemowo-świadomościowych, oraz przyczyny wewnętrzne, których źródła należy upatrywać w samej mniejszości prawosławnej. Do przyczyn zewnętrznych społecznej niepamięci można zaliczyć:

1. Brak możliwości otwartej dyskusji przed 1989 r. - a więc czynnik systemowy, związany z propagandą okresu PRL, gdy wiele tematów było przemilczanych i wykluczonych. Wiązało się to z niedopuszczaniem do otwartej dyskusji i jednocześnie niwelowaniem pamięci mniejszości narodowych.

2. Problemy z demokratyzacją pamięci w Polsce po 1989 r., rozumianej w ujęciu Bartosza Korzeniewskiego jako proces nieukończony ${ }^{34}$. Badacz wskazuje na pewien opór w zakresie demokratyzacji pamięci na gruncie polskim, zwłaszcza jeśli chodzi o odbrązowienie historii. W Polsce panuje bowiem tendencja do ukazywania w dyskursie Polaków jako ofiar krzywd wyrządzonych przez inne nacje, co wyklucza jednocześnie bycie sprawcą. Problematyczne i konfliktogenne wydaje się przyjmowanie postaw samokrytycznych oraz ukazywanie ciemnych stron polskiej historii i krzywd wyrządzonych przez Polaków przedstawicielom mniejszości.

3. Potoczne wyobrażenia o II RP - okres XX-lecia międzywojennego jest silnie zmitologizowany, dlatego wizja wyburzania chrześcijańskich świątyń z rozkazu polskich władz nie pasuje do panującego dyskursu, zdominowanego przez idee wielowiekowego (poczynając od XVI wieku) pokojowego współżycia i tolerancji religijnej, bycia „przedmurzem chrześcijaństwa”. W potocznych wyobrażeniach II RP jawi się jako kraj odnoszący sukcesy gospodarcze, którego atutem była wielokulturowość i pokojowe wspólistnienie przedstawicieli wielu narodów i wyznań.

Wszystkie wymienione elementy powodują, że temat burzenia cerkwi ulega racjonalnemu wyparciu - staje się on „ahistoryczny”, co równa się „wykluczeniu” go z historii.

Przyczyn zbiorowej niewiedzy można również szukać w obecnych ramach kulturowych i samym procesie wytwarzania pamięci społecznej, o czym pisze Sławomir Kapralski, opierając się na teorii Wulfa Kansteinera. Jak wskazuje Kapralski: [...] problem reprezentacji nie leży $w$ naturze przesztego wydarzenia, lecz teraźniejszych ram kulturowych i instytucji spotecznych, za pomoca których reprezentujemy przesztość. U podstaw trudności reprezentowania wydarzenia traumatycznego, znajduje się więc zazwyczaj jakaś forma sprzeczności, konfliktu lub braku komunikacji między czterema elementami

32 M. Hirszowicz, E. Neyman, Spoteczne ramy niepamięci, „Kultura i Społeczeństwo” 2001, vol. 45, nr 3-4, s. 24.

33 M. Kula, Nośniki pamięci historycznej, Warszawa 2002, s. 55-56.

34 B. Korzeniewski, Demokratyzacja pamięci wobec przewartościowań w pamięci Polaków po 1989 r., „Pamięć i Sprawiedliwość" 2013, vol. 22, nr 2. 
[...]: rama kulturowa, producentami, sprzedawcami i konsumentami pamięci ${ }^{35}$. Upraszczając, Kapralski wyróżnia „producentów pamięci” - to elity intelektualne i polityczne, które aktywnie tworzą wizje przeszłości; „sprzedawców pamięci” - to pośrednicy między elitami a masami; „konsumentów” - decydują oni o tym, co wybrać z dostarczonej im oferty.

Założenia poczynione przez Kapralskiego po części tłumaczą społeczną niewiedzę w zakresie akcji burzenia cerkwi, społeczność prawosławna bowiem, która przeżyła to wydarzenie, wymienionych elit, tj. „producentów pamięci”, nie wytworzyła lub wytworzyła ich zbyt mało albo są one za słabe. Brak „producentów” w tej grupie jest zatem równoznaczny z nieprzekazywaniem dziedzictwa.

Świadkowie historii również nie są „producentami” czy „sprzedawcami” pamięci są to przedstawiciele społeczności wiejskich, oddaleni od elit. Cechuje ich strach przed opowiadaniem swoich historii, również przez wzgląd na przynależność do mniejszości; też niewiedza jak opowiadać swoje historie oraz niskie kompetencje społeczne. Należy przy tym pamiętać, że „pamięć chłopska” jest z zasady niesłyszana.

Z kolei do przyczyn wewnętrznych społecznej niepamięci w zakresie opisywanej historii można zaliczyć:

1. Nieufność społeczną oraz strach mniejszości przed opowiadaniem swoich historii z obawy przed społeczną niechęcią, represjami; w starszym pokoleniu - z obawy przed powtórzeniem się historii. W powszechnej świadomości zbiorowe milczenie jest spowodowane możliwą karą i represjami, stąd obawy przed mówieniem i publicznym upominaniem się o upamiętnienie traumatycznych wydarzeń.

2. Milczenie „świadków historii” - jest to poniekąd skutek wymienionej wyżej nieufności społecznej.

3. Niechęć do popularyzowania „niepopularnej” historii, która stawia w złym świetle polskie władze.

4. Niechęć do obarczania młodego pokolenia trudną historią przodków w myśl zasad: „im mniej wiedzą, tym mniej pytań będą zadawać i będą bezpieczniejsi” oraz „co było, minęło, trzeba żyć dalej, po co do tego wracać". Podobnie jak w przypadku nieporuszania trudnych tematów na forum publicznym w obawie przed zewnętrznymi prześladowaniami trudnych tematów można również nie poruszać w obrębie grupy własnej.

\section{BURZENIE CERKWI JAKO TRAUMA W UJĘCIU (POST)PAMIĘCIOWYM}

Wśród wymienionych skutków burzenia cerkwi szczególną rolę odgrywa zbiorowa trauma, którą wydaje się obarczona społeczność prawosławna. Jest to trauma nieprzepracowana, jeśli weźmie się pod uwagę wymienioną nieufność społeczną, niechęć do publicznego podejmowania tematu, milczenie świadków historii i jednocześnie problem z przekazem trudnych doświadczeń kolejnym pokoleniom. Przyczynia się to do

35 S. Kapralski, Naród z popiotów. Pamięć zagtady a tożsamość Romów, Warszawa 2012, s. 64. 
tego, że następna generacja pełni funkcję wtórnego jej nosiciela, a sama trauma zamiast ulec „wyciszeniu”, ewoluuje, a w sprzyjających okolicznościach powraca.

Na tak pojmowanej traumie w dużej mierze opiera koncepcja postpamięci zaproponowana przez Marianne Hirsch ${ }^{36}$. Jakkolwiek Hirsch i inni „postmemorialni” badacze skupiają się i przedstawiają w swoich badaniach przykład Holokaustu jako traumy nadrzędnej w postpamięciowym dyskursie, to odkryte i działające tu mechanizmy mogą być przekładalne i służyć opisowi innych traum, takich jak wojny, przesiedlenia, wygnania, uchodźstwa, ludobójstwa. Potwierdza to uniwersalność koncepcji postpamięci, jej niezależność od czasu i miejsca. Owa przekładalność dotyczyć ma zbiorowości, które w jakimś okresie zostały dotknięte zbiorową traumą lub traumatycznymi kulturowymi wydarzeniami - zwłaszcza jeśli są to historie podrzędne. Do takich można zaliczyć przedstawianą tu historię burzenia cerkwi prawosławnych.

Przynajmniej do lat 90. XX w. dochodziło do zbiorowego zapominania o historii burzenia cerkwi, ale i instytucjonalnego przemilczania tego wydarzenia, przez co jego „wyparcia”. Dopiero po tym czasie zostało ono ponownie „odkryte”, co można utożsamiać z przywracaniem pamięci o nim. Symptomami przywracania pamięci o burzeniu cerkwi są obchody rocznicowe, pomniki, tablice, artykuły w czasopismach mniejszościowych czy książki ${ }^{37}$. Mimo wąskiego odbioru, kierowania tych treści głównie do mniejszości przez mniejszość, można w tym upatrywać postpamięciowych, twórczych „kreacji” czy „projekcji” tego wydarzenia, zastępujących bezpośrednie doświadczenia i wspomnienia. Tak zarysowane działania kolejnych pokoleń są również ukierunkowane na prezentowanie i upowszechnianie tego, co jest „niedostatecznie zaświadczone” przez „świadków historii”. Jak wskazuje Hirsch, odbywa się to poniekąd w imieniu świadków, jak też przeciwko nim, tj. w opozycji do ich milczenia ${ }^{38}$.

Tak rozumiana „pamięć odziedziczona” nie dotyczy jednak wyłącznie dzieci osób, które doznały traumy, podobnie jak sam proces „odpamiętywania” nie musi być krótkotrwały: Można zatożyć, że reprezentacje tak rozumianego dziedzictwa i dziedziczenia nie skończq się wraz z opowieściami „drugiego" $i$ „trzeciego pokolenia”, lecz będą opowiadanel konstruowane także przez późniejsze generacje - nie przypadkiem w ikonografii „drzewa

\footnotetext{
M. Hirsch, The Generation of Postmemory, „Poetics Today” 2008, vol. 29, nr 1.

37 Rok 1989 w Polsce, postrzegany jako początek transformacji systemowej, jest jednocześnie ważną datą w zakresie przemian pamięci o przeszłości, tj. jej demokratyzacji. Transformacja systemowa wywołała lub też spowodowała „transformację pamięci”, tj. jej przewartościowanie - przede wszystkim w sferze oficjalnej, ale i potocznej, por. B. Korzeniewski, Demokratyzacja pamięci wobec... s. 55-56. Jak ujmuje to Małgorzata Budyta-Budzyńska, transformacja umożliwiła powrót do pewnych nieobecnych wątków, wyzwoliła dyskusję o problemach dotychczas pomijanych, będących publicznym tabu oraz istniejących do tej pory jedynie w pamięci prywatnej. Ważną rolę w tym procesie odegrało „upodmiotowienie” po 1989 r. samych mniejszości i możliwość „odmrożenia” przez członków tych mniejszości historii niepopularnych, dotąd „ukrywanych”, por. M. Budyta-Budzyńska, Mniejszości narodowe - bogactwo czy problem? Instytucjonalizacja mniejszości narodowych w Polsce w latach 1989-2002, Warszawa 2003, s. 265.
} 
genealogicznego" ważna funkcje spetniają roztożyste gatęzie i nowe rozgatęzienia, które można interpretować jako symbol powtarzalności i „odrastania" ${ }^{39}$.

W opisywanym przypadku traumę należy charakteryzować jako zjawisko ambiwalentne, niemające jedynie destrukcyjnego charakteru: stanowi ona również „budulec” tożsamości, gdyż niesie za sobą potencjał refleksyjny dla zbiorowej tożsamości, problematyzując przy tym istnienie grupy. W tym rozumieniu traumę można postrzegać jako konstruktywną, konsolidującą i mobilizującą. Co więcej, wydarzenia, które są uważane za traumatyczne, nie muszą takie być $\mathrm{z}$ natury: [...] trauma nie jest bowiem czymś istniejacym naturalnie, lecz czymś konstruowanym spotecznie ${ }^{40}$. Jak wskazuje Jeffrey Alexander, bardziej traumatyczne niż samo zjawisko może być jego „rekonstrukcja post-hoc”, a więc jego wspomnienie, wyobrażenie, przekazywana i tkwiąca pamięć o nim w członkach zbiorowości. Jest to również poniekąd tworzenie zjawiska na nowo nie przez bezpośrednich, a właśnie zapośredniczonych świadków.

Autorefleksja nad tragicznym wydarzeniem może być impulsem do powstawania nowych, zbiorowych form tożsamości. W odniesieniu do tego Dominick LaCapra pisze o „traumie fundującej” (założycielskiej): Niektóre z najbardziej skrajnych i zgubnych doświadczeń [...] moga zostać przeksztatcone w traumy fundujace jako [...] fundamenty życia jednostkowego $i$ zbiorowego ${ }^{41}$. W ten sposób wydarzenie traumatyczne zyskuje miano traumy założycielskiej - grupa odzyskuje/pozyskuje historię, ma poczucie posiadania przeszłości, następuje przekształcenie wydarzenia traumatycznego w pewien grupowy fundament istnienia.

Zależność ta występuje w opisywanym przypadku: historia akcji burzenia cerkwi ma fundamentalne znaczenie w procesie konstytuowania się współczesnego Kościoła prawosławnego w Polsce, zwłaszcza poprzez odwoływanie się do niej w kontekście najważniejszych wydarzeń w historii Polskiego Autokefalicznego Kościoła Prawosławnego oraz budowania współczesnej tożsamości jego wiernych również przez pamięć o dramatycznej historii z 1938 r. To właśnie zdaje się potwierdzać, że jest to rodzaj traumy fundującej. Traumatyczne doświadczenie przestaje odnosić się jedynie do przeszłości, a zaczyna wpływać na teraźniejszość oraz przyszłość, generując przy tym w jednostkach i grupach „pamięć traumatyczną”, w której nieustannie „odtwarza się” owo doświadczenie. Zatarciu ulega granica między tym, co przeszłe i teraźniejsze. W pamięci traumatycznej przesztość nie jest po prostu zamknięta, skończona historia. Wciąż żyje $w$ doświadczeniu i nawiedza czy mami jednostki lub zbiorowości ${ }^{42}$.

39 A. Artwińska, Transfer międzypokoleniowy, epigenetyka $i$ „więzy krwi”: O Małej Zagładzie Anny Janko $i$ Granicy zapomnienia Siergieja Lebiediewa, „Teksty Drugie. Teoria literatury, krytyka, interpretacja” 2016, nr 1, s. 27.

40 J.C. Alexander, Trauma kulturowa i tożsamość zbiorowa, [w:] tenże, Znaczenia spoteczne. Studia z socjologii kulturowej, przeł. S. Burdziej, J. Gądecki, Kraków 2010, s. 196.

41 D. LaCapra, Historia w okresie przejściowym. Doświadczenie, tożsamość, teoria krytyczna, przeł. K. Bojarska, Kraków 2009, s. 78.

42 Tamże, s. 76. 


\section{BIBLIOGRAFIA}

Abel (Popławski) abp., Stowo Prawostawnego Arcybiskupa Lubelskiego i Chetmskiego, [w:] Akcja burzenia cerkwi prawostawnych na Chetmszczyźnie i potudniowym Podlasiu w 1938 roku. Uwarunkowania, przebieg konsekwencje, red. G. Kuprianowicz, przeł. M. Łukaszuk-Piekara, A. Saweneć, Chełm 2009.

Alexander J.C., Trauma kulturowa i tożsamość zbiorowa, [w:] tenże, Znaczenia spoteczne. Studia z socjologii kulturowej, przeł. S. Burdziej, J. Gądecki, Kraków 2010

Artwińska A., Transfer międzypokoleniowy, epigenetyka i „więzy krwi”: O Małej Zagładzie Anny Janko $i$ Granicy zapomnienia Siergieja Lebiediewa, „Teksty Drugie. Teoria literatury, krytyka, interpretacja" 2016, nr 1, https://doi.org/10.18318/td.2016.1.2.

Budyta-Budzyńska M., Mniejszości narodowe - bogactwo czy problem? Instytucjonalizacja mniejszości narodowych w Polsce w latach 1989-2002, Warszawa 2003.

Dylągowa H., Dzieje unii brzeskiej (1596-1918), Warszawa-Olsztyn 1996.

Grzesiak K., Akcja burzenia cerkwi na Lubelszczyźnie w roku 1938 - konsekwencje kulturowe, „Roczniki Kulturoznawcze” 2013, vol. 4, nr 1.

Grzesiak K., Diecezja lubelska wobec prawostawia w latach 1918-1939, Lublin 2010.

Historia Polski w liczbach. Ludność, terytorium, Główny Urząd Statystyczny, oprac. A. Wyczyński i in., red. F. Kubiczek i in., Warszawa 1993.

Hirsch M., The Generation of Postmemory, „Poetics Today” 2008, vol. 29, nr 1, https://doi. org/10.1215/03335372-2007-019.

Hirszowicz M., Neyman E., Spoteczne ramy niepamięci, „Kultura i Społeczeństwo” 2001, vol. 45, nr 3-4.

Kapralski S., Naród z popiotów. Pamięć zagtady a tożsamość Romów, Warszawa 2012.

Kęsik J., Udziat wojska w akcji rewindykacyjno-polonizacyjnej we wschodnich i potudniowych powiatach województwa lubelskiego w latach 1937-1939, „Kwartalnik Historyczny” 2014, vol. 121, nr 4, http://dx.doi.org/10.12775/KH.2014.121.4.03.

Kinasz A., Proces likwidacji prawostawnych cerkwi na Lubelszczyźnie w latach 1937-1938 w świetle relacji świadków, „Studia Sandomierskie. Teologia, filozofia, historia” 2010, vol. 17, nr 1-2.

Kiryłowicz S., Z dziejów prawostawia w II Rzeczypospolitej Polskiej. Niektóre problemy na tle polityki wyznaniowej państwa 1918-1939, Warszawa 1985.

Korzeniewski B., Demokratyzacja pamięci wobec przewartościowań w pamięci Polaków po $1989 \mathrm{r}$, „Pamięć i Sprawiedliwość” 2013, vol. 22, nr 2.

Kula M., Nośniki pamięci historycznej, Warszawa 2002.

Kuprianowicz G., 1938. Akcja burzenia cerkwi prawostawnych na Chetmszczyźnie i Potudniowym Podlasiu, przeł. A. Saweneć, Chełm 2008.

LaCapra D., Historia w okresie przejściowym. Doświadczenie, tożsamość, teoria krytyczna, przeł. K. Bojarska, Kraków 2009.

Mironowicz A., Kościót prawostawny na ziemiach polskich w XIX i XX wieku, Białystok 2005.

Mironowicz A., Kościót prawostawny w dziejach dawnej Rzeczypospolitej, Białystok 2001.

Moroz A., Między pamięcia a historią. Konflikt pamięci zbiorowych Polaków i Biatorusinów na przyktadzie Romualda Rajsa „Burego", Warszawa 2016. 
Papierzyńska-Turek M., Uwarunkowania i skutki polityczne masowego burzenia cerkwi prawostawnych u schytku II Rzeczpospolitej, [w:] Akcja burzenia cerkwi prawostawnych na Chetmszczyźnie i potudniowym Podlasiu w 1938 roku. Uwarunkowania, przebieg konsekwencje, red. G. Kuprianowicz, przeł. M. Łukaszuk-Piekara, A. Saweneć, Chełm 2009.

Poczykowski R., Lokalny wymiar pamięci. Pamięć zbiorowa i jej przemiany w pótnocno-wschodniej Polsce, Białystok 2010.

Rykała A., $O$ „topografii pustki” w krajobrazie kulturowym. Miejsca niepamięci i nie-miejsca pamięci w kontekśsie mordów dokonanych na Żydach w Polsce w pierwszych miesiącach po drugiej wojnie światowej, „Studia z Geografii Politycznej i Historycznej” 2018, vol. 7, http://dx.doi. org/10.18778/2300-0562.07.04.

Sawa (Hrycuniak) metropolita, Wstęp, [w:]: G. Kuprianowicz, 1938. Akcja burzenia cerkwi prawostawnych na Chetmszczyźnie i potudniowym Podlasiu, przeł. A. Saweneć, Chełm 2008.

Stawecki P., Następcy komendanta. Wojsko a polityka wewnętrzna Drugiej Rzeczypospolitej w latach 1935-1939, Warszawa 1969.

Anna MOROZ - doktorantka w Instytucie Socjologii Uniwersytetu w Białymstoku. Zainteresowania badawcze: pogranicze, konflikty o pamięć, pamięć zbiorowa, epigenetyka. 